\title{
Two Picnometers of Increased Convenience and Precision
}

\author{
Arnold Johnson*
}

(Received 1 June 1964)

\begin{abstract}
Two picnometer designs that provide increased convenience and precision in the determination of the density of liquids are discussed. Both designs provide ready access to the capillary tubes and reservoir area, thus facilitating the removal of excess liquid and setting of the liquid level. The standard deviation of a series of calibrations with water using the earlier of these devices, the Collett picnometer, was $0.001 \mathrm{ml}$ to $0.002 \mathrm{ml}$ over the range 5 to $70{ }^{\circ} \mathrm{C}$; with a Collett picnometer recently modified by the author and presently usable only above room temperature, the standard deviation was $0.0002 \mathrm{ml}$ to $0.0005 \mathrm{ml}$ over the range 40 to $50{ }^{\circ} \mathrm{C}$. (The weighing procedure used to calibrate the author's picnometer differed from that used with the Collett picnometer.) These data apply to picnometers of 50 to $70 \mathrm{ml}$ internal volume.
\end{abstract}

Many picnometers are inconvenient to use in that a great deal of time and care must be taken in the cleaning and drying of the surface of the overflow region after the contents have been brought to the desired temperature. ${ }^{1}$ Two picnometers have been developed which provide ready access to the overflow region. The ease of manipulation and inherent precision of these designs when used as described in this paper have been established through a series of calibrations with air-free water. ${ }^{2}$

The earlier (1950) of these two designs, that of C. T. Collett, is shown in figure 1. While the reservoir of this picnometer is more readily accessible than that of most conventional picnometers, some difficulty is experienced, especially with viscous liquids, in cleaning and drying the reservoir. The Collett design was therefore modified by the author (1961), as shown in figure 2, a removable reservoir being used. With a removable reservoir the capillary tubes can easily be wiped clean (using solvents, if necessary) after the reservoir has been slipped off, and the possibility of solvents entering the capillaries is greatly reduced. The Collett picnometer has been successfully used, in normal practice, from 5 to $70^{\circ} \mathrm{C}$. The author's picnometer is limited to use above room temperature, no provision being made at present for retaining the liquid that would expand upon a temperature rise.

Borosilicate glass was used in the construction of both picnometers, careful annealing, followed by aging for several months, being necessary to insure dimensional stability. The top of the inside of the body of both picnometers was streamlined to diminish the possibility of bubbles becoming entrapped during filling. The glass at the junctions of the tubes on the inside of the reservoir of the Collett picnometer was smoothly rounded to facilitate cleaning and the top surfaces of the capillary tubes of both picnometers were ground to make the tubes equal in height.

\footnotetext{
*Present address: David Taylor Model Basin, code 755 , Washington, D.C.
1 For example, see some of the picnometers illustrated in NBS Circ. 487 (Mar 1950 ) Density of Solids and Liquids, P. Hidnert and E. L. Peffer, and reprinted
. in Vol. II of NBS Handbook 77, p. 659/1

2 The density of water was taken from NBS Circular 19, Standard Density and Volumetric Tables. The table on page 47 was used for determinations below $41^{\circ} \mathrm{C}$. In using the table on page 46 for the determinations above $41^{\circ} \mathrm{C}$, values were assumed exact to 7 decimal places.
}

A reservoir for the author's picnometer can be made from a rubber stopper by working a cork borer part way into the stopper (a No. 6 $\frac{1}{2}$ rubber stopper and a 1 in. diam. borer were used in this work), turning inside-out the rubber on the outside and cutting across the cylinder of rubber exposed in the center. The holes for the capillary tubes are then cut through the remainder of the stopper, as shown in figure 2. The usual rubber stoppers work well with water and many other liquids; other flexible materials may be used with liquids that are contaminated by the usual rubber stoppers.

The manipulations of each of the picnometers, i.e., cleaning, filling, and weighing, were almost identical both for the calibration of the instrument and for its use in determining the density of a liquid.

The Collett picnometer was prepared for use by careful cleaning. The interior was blown dry with air that had been passed successively through sulfuric acid and calcium chloride. The exterior was first wiped with cheesecloth soaked in ethanol and then wiped with lens tissue. The clean picnometer was then exposed to ions created by a polonium strip to remove external electrostatic charges.

The picnometer and its cap were then suspended below one pan of a balance, a similar counterpoise picnometer of nearly equal mass and volume being suspended from the other pan. The use of a counterpoise picnometer reduces the number of measurements and simplifies calculations. ${ }^{3}$ A metallic counterpoise weight was put on the pan holding the counterpoise picnometer, and mass standards were added to the other pan to achieve a balance.

The picnometer was filled through a funnel which was attached by a short piece of plastic tubing to the glass tube extending into the interior, the latter being necessary to prevent direct loss of liquid out the other capillary during vacuum filling. Enough liquid was added to the reservoir to cover the tubes.

With the ground glass stopper in place, the picnometer was immersed in a water bath so that the surface of the water was slightly below the top of

${ }^{3}$ Simplification of calculations in routine density and volumetric determinations, C. T. Collett, J. Res. NBS 52, 201 (April 1954) RP 2489. 


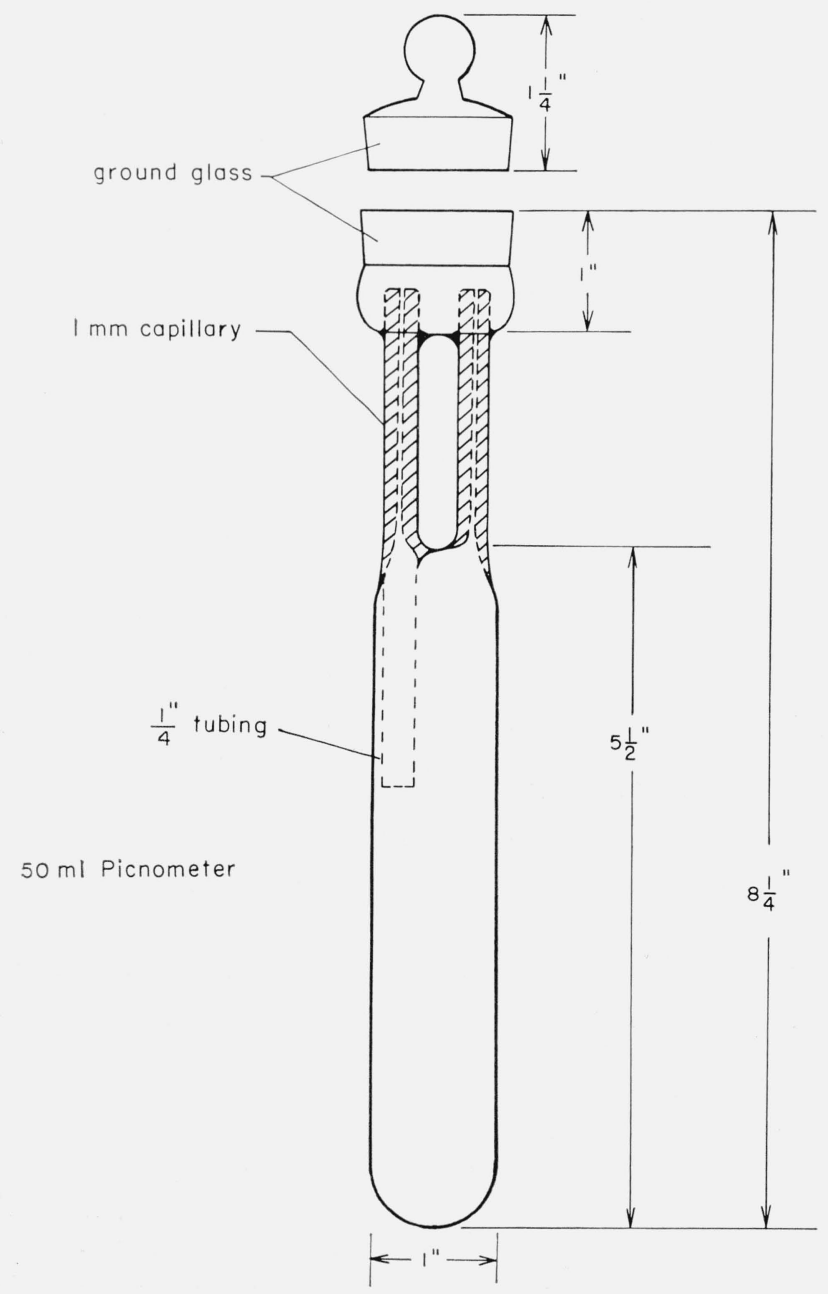

Figure 1. Collett picnometer.

the reservoir. The bath can be controlled to within $\pm 0.002{ }^{\circ} \mathrm{C}$ at $25{ }^{\circ} \mathrm{C}$; the ability to control decreases gradually to about $\pm 0.004{ }^{\circ} \mathrm{C}$ at $70^{\circ} \mathrm{C}$.

After the picnometer and contents attained the temperature of the bath, most of the liquid in the reservoir was removed with a syringe. Small absorbent swabs were used to clean and dry the reservior and to set the liquid level even with the top of the capillary tubes. The picnometer was then removed from the bath and externally recleaned and reexposed to a polonium strip as before. It was put back on the balance and mass standards were removed from its pan until a balance was achieved. Barometric pressure, temperature, and relative humidity were recorded at the time of the final weighing to permit calculation of the air density to be used in buoyancy corrections.

During the calibration of the author's picnometer, the procedures were similar to those described except for weighing. The method of weighing using a counterpoise picnometer, although decreasing the number of measurements and simplifying the calculations, is a substitution weighing in which
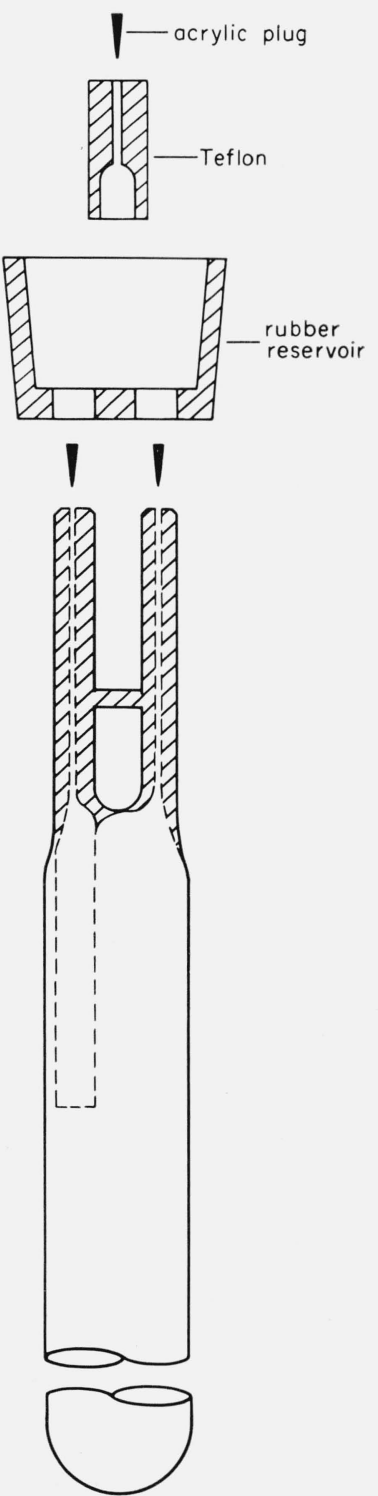

Figure 2. Author's picnometer.

several hours pass between the first and second halves of the weighing. As the rest point of a balance can change with time, this delay may lead to errors. To avoid these errors, no counterpoise picnometer was used when calibrating the author's picnometers. A substitution weighing with a minimum delay between each half of the weighing was used to determine the mass of the empty picnometer. The same procedure was followed to determine the mass of the picnometer and its contents after being filled. Buoyancy corrections were applied in both weighings.

After determining the mass of the empty picnometer, the rubber reservoir was slipped over the capillary tubes, and the picnometer was filled in the same manner as the Collett picnometer. In the temperature bath a plastic cover rested lightly on top of the reservoir. When thermal equilibrium 
was reached, most of the liquid was removed from the reservoir by a syringe, the liquid level in the capillaries was set, the picnometer was quickly removed and the body of the picnometer was immersed in cool water. The liquid rapidly retreated down the capillaries, and small tapered plugs (in this work, drawn from $1 / 16$ in. diam. rods of acrylic plastic), whose mass had been separately determined, were inserted tightly into the tubes. The rubber reservoir was carefully removed and the picnometer was cleaned, exposed to a polonium strip, and weighed as previously described.

To demonstrate that the acrylic plugs kept the evaporation loss to within the precision of the balance during the time required for the weighing; the filled picnometer was weighed three times over a period of about $2 \mathrm{hr}$ during the calibration. Statistical tests indicated that during this period no detectable loss of mass occurred. Over extended periods, however, some evaporation can take place, with up to a milligram being lost overnight. (A few overnight tests of the Collett picnometer indicated a somewhat greater mass loss. However, the rate was such that during the relatively short period required for cleaning and weighing, the total loss was of no consequence.)

For a period of 10 or 15 min after each cleaning, the picnometers, empty or filled, increased in mass by about $1 \mathrm{mg}$. This increase in mass was assumed to be moisture being readsorbed onto the suriace of the picnometer. Weighings of the picnometer, empty or filled, were performed at least $30 \mathrm{~min}$ after the picnometer had been cleaned, ionized, and suspended from the pan of the balance.

At $50{ }^{\circ} \mathrm{C}$ and above, the procedure with the author's picnometer was modified to reduce evaporation from the capillaries. While the picnometer was still in the bath, and after one tube had had its liquid level set, a Teflon cylinder (see fig. 2) with a small hole in the top was slipped over this tube, and a tapered acrylic plug loosely fitted into the hole. The other tube was similarly capped after its liquid level had been set. The picnometer was then removed from the bath and immersed in cool water, the Teflon cylinders removed, and the capillaries plugged as before.

For work with both picnometers at about $50{ }^{\circ} \mathrm{C}$ or above, it is necessary with some liquids, especially water, to inhibit the formation of bubbles. This was done by having the liquid in the picnometer at a temperature higher than that of the bath at the time of immersion. (By using this technique, one set of Collett picnometers has recently been calibrated successifully at the National Bureau of Standards to as high as $85^{\circ} \mathrm{C}$.)

Recent tests indicated that interior electrostatic charges, created by the passage of dry air, can lead to slight inaccuracies in the determination of the mass of an empty picnometer. Apparent changes of up to $1 \mathrm{mg}$ occurred when using air passed through sulfuric acid and calcium chloride; when super-dry nitrogen was used the change was $2 \mathrm{mg}$ or more. The use of a counterpoise picnometer during the calibra-
TABLE 1. Results of the calibration of the picnometers

\begin{tabular}{|c|c|c|c|c|}
\hline $\begin{array}{l}\text { Picnometer } \\
\text { designation }\end{array}$ & $\begin{array}{l}\text { Nominal } \\
\text { capacity }\end{array}$ & $\begin{array}{l}\text { Temperature or } \\
\text { range of tem- } \\
\text { perature at } \\
\text { which calibrated }\end{array}$ & $\begin{array}{c}\text { Standard } \\
\text { deviation a }\end{array}$ & $\begin{array}{l}\text { Degrees of } \\
\text { freedom }\end{array}$ \\
\hline $\begin{array}{c}52 \\
53 \\
55 \\
56 \\
(52,53,55,56) \\
71 \\
72 \\
73 \\
74 \\
\\
\mathrm{~S} \\
151 \\
151 \\
151 \\
151 \\
152 \\
153\end{array}$ & $\begin{array}{l}m l \\
50 \\
50 \\
50 \\
50 \\
50 \\
70 \\
70 \\
70 \\
70\end{array}$ & $\begin{array}{r}\text { Collett } \\
{ }^{\circ} C \\
5-70 \\
5-70 \\
5-70 \\
5-70 \\
40-50 \\
5-70 \\
5-70 \\
5-70 \\
5-70 \\
\\
\text { Johnson } \\
40 \\
40 \\
45 \\
50 \\
40-50 \\
40 \\
40\end{array}$ & $\begin{array}{c}m l \\
0.0016 \\
.0015 \\
.0010 \\
.0014 \\
\text { b. } 0011 \\
.0013 \\
.0015 \\
.0021 \\
.0017 \\
\\
\\
.00024 \\
.00023 \\
.00045 \\
.00030 \\
\text { b. } .00031 \\
.00016 \\
\text { c. } .00048\end{array}$ & $\begin{array}{r}22 \\
22 \\
22 \\
22 \\
20 \\
22 \\
22 \\
23 \\
22 \\
\\
\\
\\
25 \\
22 \\
8 \\
13 \\
44 \\
10 \\
10\end{array}$ \\
\hline
\end{tabular}

a Standard deviations over temperature intervals computed from the residuals of a least squares fit of a straight line to the data.

b Pooled estimate of standard deviations.

c Tops of capillary tubes hemispherically shaped.

tion of the Collett picnometer before the importance of internal electrostatic charges was fully realized provided a possible additional source of error.

The experimental results in the calibration of the author's picnometer did not indicate the same weighing problem mentioned above when the picnometer was filled with water. Assuming electrostatic charges to have been on the interior surface, they were conducted away during the filling through the stream of water between the picnometer and the flask from which water was being poured.

A vacuum drying technique in which the picnometer was maintained at a pressure of about $5 \mathrm{~mm}$ of $\mathrm{Hg}$ for at least $3 \mathrm{hr}$ at room temperature was tried. (Ionization of the air inside the picnometer did not seem practical with these picnometers because of the capillary entrances.) Aiter removal from the vacuum the picnometer was weighed. Successive weighings sometimes indicated that the mass was increasing; however, successive weighings on the following day always indicated that the mass had become constant to within the precision of the balance. The gain in mass was probably due to the readsorption of vapors and gases which had been lost under vacuum; therefore, it would appear to be advisable to perform weighings of the empty picnometer, externally cleaned and exposed to a polonium strip as usual, on the day following removal irom the vacuum.

Table 1 shows the standard deviations achieved in calibration at different temperatures with picnometers representing both designs. ${ }^{4}$ The small standard deviations achieved with the author's picnometer may be the result of one or more of the following considerations: (1) the feature of a removable reservoir, (2) the different weighing procedures used (delayed substitution with Collett picnometer, immediate substitution with the author's picnometer) and, (3) the weighing problem which

4 The standard deviations over temperature intervals were computed from the residuals of at least squares fit of a straight line to the data points. The calibrations of both picnometers were performed over a period of time which lasted from several weeks to several months. 
appeared to be created by electrostatic charges inside an empty air-dried picnometer.

The Collett design has been in continuous use at the National Bureau of Standards for over 10 years in the determination of the density of submitted samples. Examples of the reproducibility obtained using Collett picnometers are listed in table 2. In general, the reproducibility is not as good for volatile liquids as for the nonvolatile, as would be expected. The author's picnometer is rather new and has yet to be tested with liquids other than water.

TABLE 2. Results of density determinations with the Collett picnometer

\begin{tabular}{|c|c|c|c|c|}
\hline $\begin{array}{l}\text { Name or descrip- } \\
\text { tion of submitted } \\
\text { sample }\end{array}$ & $\begin{array}{l}\text { Nominal } \\
\text { temperature } \\
\text { range }\end{array}$ & $\begin{array}{c}\text { Density (to } 2 \\
\text { decimal places) } \\
\text { at center of } \\
\text { temperature } \\
\text { range }\end{array}$ & $\begin{array}{l}\text { Standard } \\
\text { deviation a }\end{array}$ & $\begin{array}{l}\text { Degrees of } \\
\text { freedom }\end{array}$ \\
\hline Rapeseed oil_. & ${ }^{\circ} C_{10-20}$ & $g / m l \quad 0.91$ & $\begin{array}{l}g / m l \\
0.000006\end{array}$ & 10 \\
\hline Octoil S b.... & $20-30$ & .91 & .000004 & 10 \\
\hline $\mathrm{N}$-Oil b_...... & $55-65$ & .86 & .000014 & 6 \\
\hline Manometer fluid... & $20-35$ & 2.86 & .000305 & 8 \\
\hline Manometer fluid... & $27-38$ & 1. 23 & .000086 & 7 \\
\hline Chloroform _...... & $22-28$ & 1. 48 & .001577 & 12 \\
\hline Toluene.. & $16-32$ & 0.86 & .000058 & 10 \\
\hline Silicone fluid........ & $65-75$ & .93 & .000022 & 8 \\
\hline 2-ethylhexane & $15-25$ & .83 & .000032 & 4 \\
\hline Ethanol_..._. & $18-29$ & .81 & .000024 & 7 \\
\hline Sea water & 4 & 1.03 & c. 000046 & 20 \\
\hline
\end{tabular}

a Standard deviations over temperature intervals computed from the residuals of a least squares fit of a straight line to the data.

b NBS standard viscosity sample. A description of all NBS standard materials can be found in Misc. Publ. 241, Standard Materials, available from the Superintendent of Documents, U.S. Government Printing Office, W ashington, D.C., 20402.

c Pooled estimate of standard deviation based on 10 samples.
Two Collett picnometers have recently been recalibrated at temperatures above room temperature using tapered acrylic plugs and Teflon cylinders to reduce evaporation at $50{ }^{\circ} \mathrm{C}$ and above, and using the counterpoise picnometer method of weighing. The standard deviations obtained were comparable to those for the Collett picnometer listed in table 1 .

A modification that was tried recently, and which seems promising, is the use of capillary tubes that have a ground hemispherically shaped top. With water, at least, the menisci are practically self-setting, since during the experiment no wiping of the capillary tubes was performed (see last item in table 1). Another possible modification is the use of fused quartz to decrease thermal expansion and the inclusion of a radioactive material in the quartz to eliminate electrostatic charges.

The advantages of the removable reservoir of the author's picnometer can be better evaluated through density determination of different types of liquids after the calibration has been extended over a wider temperature range. For use below room temperature, it will be necessary to provide expansion chambers, perhaps made of Teflon, that will attach to the top of each capillary tube, the reservoir then being removed by destruction. A removable reservoir will greatly reduce the problem of drying condensation when the picnometer is used below the dew point.

The author expresses his appreciation to C. T. Collett for many helpful discussions and to William Gallagher for techniques and data on the Collett picnometer.

(Paper 69C1-178) 